\title{
Book Review - New Directions in University Education: Perspectives from the Caribbean
}

Editors: Elizabeth F. Watson \& Jamillah Grant Barbado (2007). New Directions in University Education: Perspectives from the Caribbean. Barbados: The Learning Resource Centre, The University of the West Indies (220 pages). ISBN: 978-976-8251-71-0.

Reviewer: Judith Soares, University of the West Indies, Barbados

At a time when universities and other institutions of higher education worldwide are increasingly embracing the virtual environment for learning, and pursuing new educational techniques to maximise student learning and knowledge creation, The University of the West Indies (UWI) is determined to place greater emphasis on quality teaching and improved learning, and on removing existing barriers to people in the pursuit of higher education in the region UWI serves.

In its bold efforts to be innovative and to encourage the search for and creation of knowledge, The UWI, a three-campus entity, faces challenges, which are not uncommon to universities, particularly those in the countries in the south. The progress and challenges of this institution are recorded in the recently published New Directions in University Education: Perspectives from the Caribbean edited by Elizabeth F. Watson, founding librarian of The UWI's Learning Resource Centre and Jamillah Grant, the institution's Instructional Development Specialist, both of whom are located at the Barbados campus. This collection of 10 essays records The University of the West Indies' tertiary level education initiatives, which include the location of the student at the centre of the learning process. These initiatives, with lessons for the developing world, range from the integration of information communication technology into the institution's programme of activities, to information delivery and curriculum development.

The book appropriately opens with Michael L. Thomas' “The Liberalization of Higher Education: Its impact and implications for The UWI and tertiary education in the Anglophone Caribbean Potentials and risks for the delivery of cross-border education”. This article, which makes excellent reading, is very timely, and comes at a time when the liberalization of higher education in the region is offering, at the same time, both benefits and challenges. Thomas' critical examination of the very real issues involved in cross-border education, a consequence of the General Agreement on Trade in Services (GATS), indicates that the decision to open up all markets to the provision of private educational services can work against the best interests of our region, presenting, as it were "serious and substantial threats to the very existence of a vigorous public education system” (p.51). This piece has relevance not only for the Caribbean, but for the entire developing world. 
Jamillah Grant's and Elisabeth Bladh's innovative "Teaching French in the Anglophone Caribbean: A Barbadian perspective,” highlights the problems French language students faced in fully developing their competence in this field of study. They argue for technological interventions to enhance the ability of students to master the French language. In this respect, the authors offer relevant advice on creating an environment of learning which would allow for greater proficiency and fluency in this foreign language.

Complementing this approach is Elizabeth Watson's "Videos in the Classroom: Experiences from a developing country," which supports and promotes the use of the video as a learning tool. In this piece, Watson highlights the role of The UWI's Learning Resource Centre as an educational support unit that values the use of commercially-produced videos in curriculum delivery at the Barbados campus. Though speaking to the experience in Barbados, I feel Watson's work has relevance to all learning situations and academics/ instructors who can appreciate the importance of video-graphic information services. Jamillah Grant's second contribution as sole author, "Instructional Development: Just-in-time delivery supports teaching, learning and selfdevelopment” seems novel in advising on the way in which 'just-in-time' support services can be effective in the absence of technological delivery systems.

In Kathleen Helenese-Paul's "The Library and the Museum: an outline of strategies for enhancing access at The UWI Main Library, St. Augustine,” we learn of the significance of the library in supporting teaching, learning and research and that of the museum, not just in providing information, but in connecting the individual with their history, their heritage and their culture in a very practical and organic way. Focusing on the experience of The UWI's campus in Trinidad and Tobago, Helenese-Paul takes the reader into a world of personalized and social learning offered by history and culture. Sharon Alexander-Gooding takes up the very important and indispensable practice of records management. In her contribution to this book, "Training Records Managers and Archivists: Tradition and innovation at the UWI Cave Hill - "Running to keep walking in the information race" Alexander-Gooding argues more emphasis needs to be placed on records management because "[S]uch records support business and strategic directions, document decisions, ensure accountability and capture corporate memory” (p. 68).

No less important is Ingrid Iton's “Creating Synergies in Information Literacy Instruction: A Caribbean Higher Education Perspective," which presents a sharp analysis of The UWI's newly introduced programme of information literacy at the Main Library at the Barbados campus. In her evaluation, Iton concludes that for learning to take place and for the project to be more effective, librarians and the library must be integrated into all academic programme activities. The use of 'role playing' in the teaching of computer studies to upper level students at the Barbados campus is the focus of Colin Depradine's essay. This is a method of teaching, which according to Depradine will allow The UWI to produce students/ professionals who are both efficient and effective in the field of computer programming. In his "Using role-playing tools to teach advanced computer programming in the Caribbean,” Depradine argues that role-play enables students “to apply abstract techniques to real-world situations” (p. 85).

Information technologies also come up for discussion with specific reference to programmes being implemented in the Caribbean. Permanand Mohan and Ben Kei Daniel analyse the existing use of Caribbean Learning Object Repositories for Education (CaribLORE) a blended learning model introduced to incorporate new and emerging technologies of learning, critical to enhancing 
and expanding The UWI's reach in distance education and distance learning. Their discussion has value for the global community of distance education providers who are intent on implementing successful models of distance learning. In similar vein, Gerard H. Rogers' "ALN at the UWI: A look at institutional readiness and other key issues" focuses specifically on the advantages and disadvantages of Asynchronous Learning Networks (ALN) at The UWI. Specific reference is made to the Trinidad and Tobago Campus in a discussion which raises issues of quality assurance, inadequate physical infrastructure, increasing student enrollment, the sustainability of programmes, and the institution's readiness to take on new approaches to expand learning.

Overall, the text reads very well and is a useful companion to all those involved in distance education and open and blended learning. More importantly, however, this book is of invaluable worth to The UWI and other like institutions, which are embracing new directions in the delivery of higher education.

One flaw is evident. The book carries two different titles: "New Directions in University Education: Perspectives from the Caribbean" and "New Directions in University Education: Perspectives from the developing world." The good new is that is inadvertent error does not take away from the quality of the publication. 